NBER WORKING PAPER SERIES

\title{
PRICING TO MARKET IN JAPANESE MANUFACTURING
}

Richard C. Marston

Working Paper No. 2905

\section{NATIONAL BUREAU OF ECONOMIC RESEARCH 1050 Massachusetts Avenue Cambridge, MA 02138 \\ March 1989}

I would like to thank Robert Cumby, Catherine Mann, Gary Saxonhouse, and participants at seminars at the International Monetary Fund and University of Delaware for their helpful comments on an earller draft. This paper is part of NBER's research program in Internatlonal studies. Any opinions expressed are those of the author not those of the National Bureau of Economic Research. 
NBER Working Paper \#2905

March 1989

PRICING TO MARKET IN JAPANESE MANUFACTURING

\section{ABSTRACT}

This paper investigates pricing by Japanese manufacturing firms in export and domestic markets. The paper reports equations explaining the margin between export prices in yen and domestic prices for a wide range of final goods including many of the electronic and transport products which have figured so prominently in recent trade discussions. Evidence is presented showing that Japanese firms respond to changes in real exchange rates by "pricing to market", varying their export prices in yen relative to their domestic prices. The empirical specification makes it possible to disentangle planned changes in the margin between export and domestic prices from inadvertent changes in this margin due to unanticipated changes in exchange rates. The degree of pricing to market varies widely across products, but there is strong evidence that pricing to market occurs. The paper also investigates whether pricing to market has increased in scale in the period since 1985 when the yen began a sustained appreciation; but finds that only five of seventeen products experienced a shift in price behavior over that period. 
In the last ten years, exporting firms in the industrial countries have had to cope with unprecedented changes in real exchange rates. In order to remain competitive, many firms in these countries are said to have followed pricing policies designed to keep export prices competitive despite changes in exchange rates. In response to an appreciation of the domestic currency, for example, these firms have reduced the domestic currency prices of products destined for export markets in order to limit increases in the foreign currency prices of these products such pricing behavior, because it opens up a margin between export and domestic prices of the same product, has been termed "pricing to market" by Krugman (1987) and cthers 1

This paper examines the pricing to market behavior of Japanese manufacturing firms during the 1980 s using an unusually detailed set of export and domestic price data published by the Bank of Japan. The paper reports equations explaining the margin between export and domestic prices for a wide range of final goods including many of the electronic and transport products which have figured so prominently in recent trade discussions. For each product, pricing to market elasticities are estimated which show how changes in real exchange rates lead to variations in the ratio of export to domestic prices. The empirical specification makes it possible to disentangle planned changes in the margin between export and domestic prices from inadvertent changes in this margin due to unanticipated changes in exchange rates. 
Most previous studies of foreign pricing have focused on exchange rate pass-through rather than pricing to market. The two phenomena are closely related, as will be seen below, but estimates of pass-through elasticities depend more critically on the specification of cost functions. Estimates of pricing to market elasticities, which measure how the ratio of export prices to domestic prices respond to exchange rates, are less sensitive to exrors in specifying cost functions, since under most conditions costs have ittie if any effect on this price ratio. The first section of the paper develops a model of pricing to market based on the markup behavior of exporting firms. Markup behavior is cruciai because it is through varying markups that firms limit the impact of exchange rates on their competitiveness. Althoug the model allows for different types of demand and cost benavior, it leads to a simple pricing to market equation whioh specifies che margin between export and domestic prices as a function of real exchange rates, real wages, and other factors. The seconc section investigates how the margin between export and domestic prices may be temporarily affected by unanticipated changes in exchange rates. If fims set prices in foreign currency for more than one period, then an unanticipated depreciation or appreciation will change price margins even in the absence of pricing to market. one of the challenges of emprical work on pricing to market is to separate out these unanticipated effects from planned changes in pricing. The third section then presents empirical evidence on pricing to 
market for seventeen manufactured products. A final section summarizes some of the principal findings of this study.

\section{A Model of Pricing to Market}

Pricing to market behavior can be seen most clearly if we consider the case of a monopolist firm in the ith industry producing in the domestic country but selling in both domestic and export markets. The firm selis in the domestic market at a price $P_{i t}$ and in the export market at a price $Q_{i t}$, with $Q_{\text {it }}$ being expressed in foreign currency. If there is effective arbitrage between the two markets, then the two prices are tied together by the law of one price: $P_{i t}=S_{t} Q_{i t}$, where $S_{t}$ is the domestic currency price of foreign currency; comodity arbitrage prevents any pricing to market from occurring. If commodity arbitrage by third parties is ineffective, ${ }^{2}$ however, then the firm will in general set different prices in the two markets even when expressed in domestic currency. And the firm will vary the relative price of export to domestic goods,

$$
x_{i t}=\left(S_{t} Q_{i t}\right) / P_{i t}
$$

in response to changes in either demand or cost conditions. It is this ratio of the export to dorestic prices of the same good which is termed the export-domestic price margin.

\section{A. Demand and cost behavior}

This section describes how demand and cost behavior interact to determine this margin. Let domestic and foreign demand be described by the following functions: 


$$
h\left(\frac{P_{i t}}{P_{t}}, y_{t}\right), \quad f\left(\frac{Q_{i t}}{Q_{t}}, Z_{t}\right),
$$

where $F_{t}, Q_{t}$ are the general price levels in the domestic and foreign countries, respectively, and $Y_{t}, z_{t}$ are the leveis of real income in the two countries. The elasticities of demand in the domestic and foreign markets are given by:

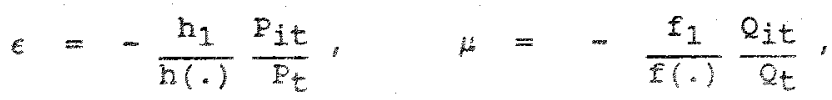

where n, Fi are the derivatives of the denand functions with respect to their first arguments, melative prices. The cost cunction axpesses costs in teme of totel owput and factor prices:

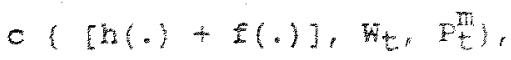

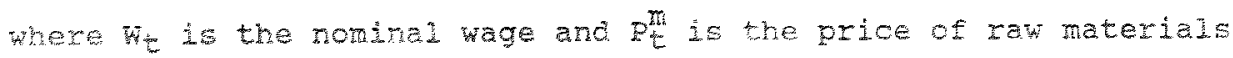
used in probution. Both factor proes are expresed in domesto currency ince al production is assumed to be done at home.

The profit function of the fim is abo expressed in donestic currency as:

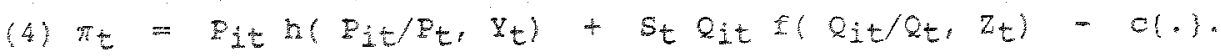
Wotice that reverues from foreign sajes are expressed in domestic currency (using the exchange rate, $s_{t}$. The first order conditions for the two markets are:

$$
\begin{aligned}
& \left(P_{1 t} n_{1}\right) / P_{t}+h(\cdot)-\left(C_{1} h_{1}\right) / P_{t}=0 \\
& \left(S_{t} Q_{1} E_{1}\right) / Q_{t}+S_{t} f(\cdot)-\left(C_{1} I_{1}\right) / Q_{t}=0 .
\end{aligned}
$$


where $c_{1}$ is marginal cost. 3 These first order conditions can be written in terms of two markup functions:

$$
\begin{aligned}
& P_{i t}=C_{1}(,) M\left(P_{i t} / P_{t}, Y_{t}\right), \\
& S_{t} Q_{i t}=C_{I}(,\} N\left(Q_{i t} / Q_{t}, Z_{t}\right) .
\end{aligned}
$$

M(.) is the markup of the domestic price over marginal cost, while $N($.$) is the markup of the foreign price (expressed in$ domestic currency) over marginal cost. Each markup is a function of the same variables as the corresponding demand function. The markup function can be mitten in terms of the elasticities of demand:

$$
M(\cdot)=\epsilon /(\varepsilon-1), \cdots N(\alpha)=\mu /(\mu-1) .
$$

If the demand elasticities are constant (case 1 below), then the markups will be constant as well. In more general cases, the markups may rise or fall as the price of the good rises.

The price in one market is generally not independent of the price in the other because each is tied to a common marginal cost. That is, since marginal cost is a function of total output, changes in one price may induce changes in the other price indirectly through changes in marginal cost in order to determine the effects of demand and cost factors on relative prices, the first order conditions are totally differentiated and solved for the domestic and export prices. In the next two sections the elasticities of these prices with respect to the independent variables are described in detail. 


\section{B. Pricing to Market: the Effects of a Depreciation}

This section examines the effects of a depreciation of the domestio currency on the foreign and domestic prices of a good produced at home. As shown below, the depreciation directiy lowers marginal costs expressed in domestic currency $\left(\mathrm{C}_{1} / \mathrm{S}_{t}\right)$, so the foreign price of the good (Qit) must fali. The domestic price of the good, in contrast, changes onIy if the depreciation leads to changes in marginal costs expressed in domestic currency. Finaly, the ratio of Eoreign to donestic prices may rise or far depending on demand and cost behavior.

Consider first the foreign currency price of the good destined for the foreign market ("the foreign price"). The elasticity of this price with respect to the exchange rate is given by:

$$
\left.\left.\beta_{1}=\mid \mathrm{d} Q_{1 t} / Q_{i t}\right) /\left(\mathrm{d} s_{t} / S_{t}\right)=-\mid H_{12} S_{t}\right) /|H|<0_{i}
$$

where $\left.\mathrm{H}_{11}=1-\left(\mathrm{C}_{1} \mathrm{M}_{1}\right) / \mathrm{P}_{t}-\left(\mathrm{M}_{1}\right) \mathrm{C}_{11} \mathrm{~h}_{1}\right) / \mathrm{E}_{t}{ }^{4}$

$$
\begin{aligned}
& \mathrm{H}_{22}=S_{t}-\left(\mathrm{C}_{1} \mathrm{~N}_{1}\right) / Q_{t}-\left(\mathrm{N}(.) \mathrm{C}_{11} \mathrm{f}_{1}\right) / Q_{t} \\
& |\mathrm{H}|=\mathrm{H}_{11} \mathrm{H}_{22}-\left[\mathrm{M}(.) \mathrm{H}(\cdot)\left(\mathrm{C}_{11}\right)^{2} \mathrm{f}_{1} \mathrm{~h}_{1}\right] /\left(\mathrm{P}_{\mathrm{t}} Q_{t}\right)
\end{aligned}
$$

and where $\mathrm{H}_{11}, \mathrm{H}_{22},|\mathrm{H}|>0$ by the second order conditions. 5 The elasticity is negative indicating that a cepreciation of the domesto currency must lower the price of this good in foreign currency. This elaticity is often called the "pass-through coeficient" since it measures the extent to which a change in the exchange rate is passed-trrough to the foreign price.

The elasticity of the price of the good destined for the 
home market ("the domestic price") with respect to the exchange rate is:

(g) $\beta_{Z}=\left(d P_{i t} / P_{i t}\right) /\left(d S_{t} / S_{t}\right)=-\left[\left(N(\cdot) C_{I I} f_{I}\right) / Q_{t}\right] /|H|$

The crucial term in this expression is $C_{11}$, the derivative of the marginal cost with respect to output. The depreciation may change the domestic price, but only if the marginal cost increases or decreases with output. That is,

$$
\frac{d P_{i t} / P_{i t}}{d S_{t} / S_{t}}<0 \text { as } \quad C_{11} \geq 0
$$

If marginal costs are constant $\left(C_{11}=0\right)$, then the coreign price alone absorbs the impact of the depreciation.

The "pricing to market" (or PTM) effect concerns the

relative price of domestic goods destined for the wo makets or $x_{i t}$ The response of $x_{i t}$ to a depreciation can be expressed in terms of the PTM elasticity, $a_{2}$ :

$$
\begin{aligned}
& \alpha_{1}=\frac{d X_{i t} / X_{i t}}{d S_{t} / S_{t}}=1+\beta_{1}-\beta_{2} \\
& =\left(-\left(T S_{t} H_{1 I}\right)+\left(\delta N(*) C_{1 I} f_{I} / Q_{t}\right) / \mid \mathrm{H}\right.
\end{aligned}
$$

where $\delta$ and, are the elasticities of the domestic and foreign markups with respect to prices:

$$
\delta=\frac{M_{1} P_{i t}}{M(\cdot) P_{t}}, \cdots,=\frac{N_{1} Q_{i t}}{N(\cdot) Q_{t}} .
$$

These markup elasticities can be positive, negative, or equal to 
zero since they reflect the curvature of the respective demand curves. 6 so the PTM elasticity can also take a variety of values. In order to focus on demand behavior, assume that marginal costs either increase or remain constant as output expands $\left(C_{11} \geq 0\right) .7$ consider the following cases:

Case 1: Constant Markups $(\delta=\tau=0)$

The markups of prices over marginal cost are a function of price elasticities alone, as 1 s evident from the makkup expression (7) above. If both demand ourves have constant price elasticities, as with a log-linear demand curve, then the markups are constant and the markup elasticities are equal to zero for 6 $=\tau=0\rangle$. In that case, the export and domestic prices are tied to comon marginal cost in $(6 a)$ and $(6 b)$, and the ratio of these prices is therefore constant:

$$
x_{i t}=\frac{s_{t} Q_{i t}}{P_{i t}}=\frac{M(\cdot)}{M(.)}
$$

so the PTM elasticity $\left(\alpha_{2}\right)$ is zero.

consider the case where marginal cost is constant $\left(c_{11}=0\right)$. E depreciation of the domestio currency $\left(s_{t}>0\right)$ leaves the domestic price unchanged $\left(\dot{2} . \mathrm{e}_{*} \beta_{2}=0\right)$, but leads to a reduction of the export price expressed in foreign currency by the same proportion as the ohange in the exchange rete $\left(\beta_{2}=-1\right)$. With complete pass-through of the exchange rate depreciation into the foreign currency price, the export price expressed in donestio currency remains constant: 


$$
\frac{d\left(S_{t} Q_{i t}\right) /\left(S_{t} Q_{i t}\right)}{d S_{t} / S_{t}}=1+\beta_{1}=0
$$

Thus not only is $x_{i t}$ constant, but so also are the prices of both domestic and export goods in domestic currency.

In the case where marginal costs are increasing, a depreciation leads to a rise in the domestic price and in the export price expressed in domestic currency equal to the rise in marginal costs. So the export price expressed in foreign currency falls less than proportionally $\left(-1<\beta_{1}<0\right)$, and passthrough is only partial. But as long as markups are constant, the ratio of export to domestic prices, both expressed in domestic currency, is constant and the PTM elasticity is again zero $\left(\alpha_{I}=0\right)$.

Case 2: Variable Markups with $\delta, \tau<0$.

In order for pricing to market to occur, markups must vary with prices. In the case of any demand curve which is less convex than a constant elasticity curve, a rise in prices reduces the markup of prices over marginal costs and a fall in prices increases this markup. This case encompasses a wide range of demand curves including any demand curve more linear than the constant elasticity curve such as the linear curve itself. ${ }^{8}$ Consider first the pass-through effect. Since a depreciation of the domestic currency lowers the foreign price (in foreign currency), it increases the markup of this price over marginal cost expressed in foreign currency. So the foreign 
price falls less than the rise in the exchange rate or the passthrough is less than complete $\left(\left|\beta_{1}\right|<1\right)$. When this price is converted back into domestic currency, moreover, it necessarily increases $\left(i . e\right.$. by $\left(1+\beta_{1}\right)>0$ in percentage tems).

If marginal costs are constant, then the domestic price is constant as well, so the margin between foreign and domestic prices (expressed in domestic currency) must widen, and the pTM elasticity is positive $\left(\alpha_{I}>0\right)$. If mareinal costs increase with output, the domestic price increases with a depreciation of the comestic curreney $\left(1, e, \beta_{2}>0\right)$, but the narkup of this price over marginai cost falls. So the margin between foreign and domestic prices still widens $\left(\alpha_{1}>0\right)$. In fact, regardiess of whether marginal costs increase or remain constant, the PTM elasticity is between zero and unity $\left(1 . e, 0<\alpha_{1}<1\right)$. So the margin between foreign and domestic prices increases by a fraction of the rise in the exchange rate.

Consider the example of Japanese goods destined for the U.S. market. If the yen depreciates, the prices of U.S.-destined goods fall in tems of dollars. But because Japanese firms increase their markups, the "pass-through" is less than proportionai to the depreciation, so the prices in terms of yer must rise. That opens a gap between the prices of goods destined for the Japanese and U.S. markets. The increase in the exportdomestic price margin can be anywere between zero and 100 percent of the depreciation. Similarly, if the yen appreciates, as it has since 2985 , then the prices of U. S, destined goods rise 
in dollars, but the increase is less than proportional to the exchange rate because the yen prices of these goods fall. As a result, Japanese goods become less expensive abroad than at home.

This second case with varying markups will be of central interest in the empirical work below. To complete the discussion of markup behavior, however, a thira possible case should be mentioned where demand curves are more convex rather than less convex than the constant elasticity case. Then markup elasticities are positive rather than negative $(\delta, \tau>0)$, and PTM elasticities are negative $\left(\alpha_{1}<0\right)$. An appreciation of the yen leads to an increase in the foreign currency prices of exports that is more than proportional to the appreciation. This third case is inconsistent with PTM behavior as usually described, but it is possible that such behavior may characterize some industries.

\section{Influence of other Factors on Foreign-Domestic Price Margins}

Any factor influencing costs or demands in either country can potentially affect the ratio of export to domestic prices. But as this section shows, cost factors influence exportdomestic price margins only under certain demand conditions. And general price levels influence export-domestic price margins in a symmetric fashion which allows these margins to be expressed in terms of real rather than nominal exchange rates.

\section{(i) Cost factors:}

According to the cost function (3), both wages and raw material prices can influence costs, and indirectly influence 
prices, in both foreign and domestic markets. In order to affect export-domestic price margins, however, these cost factors must have a differential impact on prices in the two markets. The elasticities of $x_{i t}$, the ratio of export to domestic prices, with respect to wages and raw material prices are given by the following expressions:

$$
\begin{aligned}
& \alpha_{2}=\frac{d X_{1 t}}{d w_{t}} \frac{w_{t}}{X_{1 t}}=\frac{c_{12} W_{t}}{c_{1}} \frac{s_{t}}{|H|}[\tau-\delta] \leq 0, \\
& a_{3}=\frac{d x_{i t}}{d P_{t}^{m}} \frac{F_{t}^{m}}{X_{i t}}=\frac{C_{13} F_{t}^{m}}{c_{1}} \frac{s_{t}}{H H}[\tau-\delta] \leq 0
\end{aligned}
$$

Both $\alpha_{2}$ and $\alpha_{3}$ can be expressed in terms of the markup elasticjties, $\delta$ and $T$, which measure the response of the markups to changes in prices, but it is only the difference between these elastioities that maters. If the demand curves in the two markets have constant price elasticities, then the markup elasticities are equal to zero $(\delta=t=0)$, so a rise in wages or raw material prices has no effect on the export-domestic price margin. But this is also true in the more general case where markup behavior is identical in the two markets $(\delta=\tau)$, which would be the case if the demand curves have the same curvature. 9 Then a rise in wages or raw material prices has no effect on the export-domestic price margin because it increases prices in both markets by the same percentage. Even if markup behavior is different, the margin changes only in proportion to the difference in the markup elasticities. 10 so cost factors are not a major influence on export-domestic price margins unless demand 
behavior differs substantially in the foreign and domestic markets.

\section{(ii) General price levels:}

General price levels influence export-domestic price margins through the respective demand functions. The elasticities of $x_{i t}$ with respect to the two general price levels, $Q_{t}$ and $P_{t}$, are expressed as follows:

$$
\begin{aligned}
& \frac{d x_{i t}}{d Q_{t}} \frac{Q_{t}}{X_{i t}}=\frac{d x_{i t}}{d s_{t}} \frac{s_{t}}{X_{i t}}=\alpha_{1} \\
& \frac{d x_{i t}}{d P_{t}} \frac{P_{t}}{X_{i t}}=-\alpha_{1}-\frac{s_{t}}{H_{1}}\left[\tau^{\prime}\right]
\end{aligned}
$$

A rise in the general price level in the foreign country has the same effect on $x_{i t}$ as a rise in the nominal exchange rate. And a rise in the general price level in the domestic country has a larger of smaller effect than a rise in $S_{t}$ by a factor which depends like $\alpha_{2}$ and $\alpha_{3}$ on the difference between the markup elasticities, $\tau-\delta$. In fact, the last term in (12b) can be rewritten in terms of the factor price elasticities as follows: 11

$\left(12 b^{*}\right)$

$$
\frac{d X_{i t}}{d P_{t}} \frac{P_{t}}{X_{i t}}-\alpha_{1}-\alpha_{2}-\alpha_{3}
$$

This transformation allows factor prices to be expressed in real terms below.

\section{(iii) Income Effects:}

Since demand functions in both domestic and foreign markets are a function of income in that market, the ratio of their 
prices are a function of both income variables, $Y_{t}$ and $z_{t}$. But under plausible conditions, $x_{i t}$ may be unaffected by changes in either variable. consider the elasticity of $x_{i t}$ with respect to each income variable:

$$
\begin{aligned}
& \alpha_{4}=\frac{d X_{i t}}{d Y_{t}} \frac{Y_{t}}{X_{i t}} \\
& =\frac{Y_{t}}{T H}\left\{-M_{2}\left[\frac{C_{1} H_{22}}{P_{i t}}-\frac{s_{t} C_{11} h_{1}}{P_{t}}+\frac{S_{t} C_{11} h_{2}}{C_{1}}[\tau-\delta 1\},\right.\right. \\
& \text { (13b) } \alpha_{5}=\frac{d x_{i t}}{d z_{t}} \frac{Z_{t}}{x_{i t}} \\
& =\frac{Z_{t}}{|H|}\left(N_{2}\left[\frac{C_{1} W_{11}}{Q_{1 t}}-\frac{C_{11} \hat{S}_{1}}{Q_{t}}\right]+\frac{S_{t} C_{11} E_{2}}{C_{1}}(T-\delta]\right) .
\end{aligned}
$$

These two income elasticities depend once again on the difference between the markup elasticities, $\tau-\delta$. If $\tau=\delta$, however, the income elasticities can still be non-zero if markups are directly sensitive to income las measured by the derivatives of the markup functions, $M_{2}$ and $\left.N_{2}\right)$. But this reguires that the price elasticities of the demana curves be a function of income, since

$$
M_{2}=-\epsilon_{Y} /(\epsilon-1)^{2}, \quad N_{2}=-\mu_{Z} /(\mu-1)^{2} .
$$

If the demana curves are Iinear or log-linear, for example, these elasticities are equal to zero. So changes in income could very well have no effect on export-domestic price margins.

\section{Summary of Markue Behavior:}

The model of markup benavior shows $x_{1}$ is influenced by seven demand and supply variables, but the reduced fom equation 
for $x_{i t}$ can be simplified by expressing it in terms of several relative prices:

$$
\begin{aligned}
R_{t}= & \left(Q_{t} S_{t}\right) / P_{t}=\text { the ratio of general price levels } \\
& \text { expressed in domestic currency or the "real exchange } \\
& \text { rate", } \\
w_{t} / & P_{t}=\text { the real wage (expressed in terms of domestic } \\
& \text { prices), } \\
P_{t}^{m} / & P_{t}=\text { the real price of raw materials. }
\end{aligned}
$$

The percentage change in $x_{i t}$ is given by the following expression:

$$
\begin{aligned}
\frac{d X_{1 t}}{X_{i t}}=\alpha_{1} \frac{d R_{t}}{R_{t}}+\alpha_{2}\left[\frac{d W_{t}}{W_{t}}-\frac{d P_{t}}{P_{t}}\right]+\alpha_{3}\left[\frac{d P_{t}^{m}}{P_{t}^{m}}-\frac{d P_{t}}{P_{t}}\right] \\
+\alpha_{4} \frac{d Y_{t}}{Y_{t}}+\alpha_{5} \frac{d Z_{t}}{Z_{t}}
\end{aligned}
$$

where $\frac{d R_{t}}{R_{t}}=\frac{d Q_{t}}{Q_{t}}+\frac{d S_{t}}{S_{t}}-\frac{d P_{t}}{R_{t}}$

The ratio of export to domestic prices, the export-domestic price margin, can be expressed as a function of the real exchange rate, the real wage, the real price of raw materials, and two output series. The crucial coefficient in this equation is $\alpha_{1}$, the PTM elasticity showing how the margin between export and domestic prices changes when the domestic currency depreciates or appreciates.

The empirical counterpart of this equation involves variables expressed in logs. If the log of a variable is denoted 
by a small-case letter, then the log version of (14) can be written as follows:

$$
\begin{aligned}
\text { (15) } x_{i t}= & \alpha_{1} r_{t}+\alpha_{2}\left[w_{t}-p_{t}\right]+\alpha_{3}\left[p_{t}^{m}-p_{t}\right]+\alpha_{4} y_{t} \\
& +\alpha_{5} z_{t} .
\end{aligned}
$$

In the estimation described below, all variables are expressed as changes in the logs.

\section{Price Setting and Exchange Rate Surorises}

If firms set export prices in domestic currency, or if they set export prices in foreign currency and there are no lags in price-setting, then the estimation of PTM elasticities is straightforward. But if firms preset export prices in foreign currency, observed variations in the ratio of export to domestic prices may reflect the effects of unanticipated changes in exchange rates rather than pricing to market. 12

consider the case of a firm setting export prices in foreign currency (and domestic prices in domestic currency) for period on the basis of information available at $t-1$. The firm will attempt to set export and domestic prices so that $x_{i t}$ is equal to the expected value of expression (15). That is, the firm sets git - Pit such that

(16) $q_{i t}-p_{i t}=E_{t-1}\left(q_{i t}-p_{i t}\right)$

$$
=\alpha_{1} E_{t-1} r_{t}+\alpha_{0} E_{t-1} b_{t}-E_{t-1} s_{t r}
$$

where $\alpha_{0} b_{t}=\alpha_{2}\left[w_{t}-p_{t}\right]+\alpha_{3}\left[p_{t}-p_{t}\right]+\alpha_{4} y_{t}+\alpha_{5} z_{t}$ and 
where $E_{t-I}$ denotes the expected value of a variable based on information available at $t-1$. The actual value of $x_{\text {it }}$ will differ from its expected value because of exchange rate surprises, $s_{t}-E_{t-1} s_{t}$ :

$$
\begin{aligned}
x_{i t} & =E_{t-1}\left(q_{i t}-p_{i t}\right)+s_{t} \\
& =\left(s_{t}-E_{t-1} s_{t}\right)+\alpha_{1} E_{t-1} r_{t}+\alpha_{0} E_{t-1} b_{t}
\end{aligned}
$$

With a price-setting lag of one period, a depreciation of the domestic currency in period $t$ will raise $x_{i t}$ not because of pricing to market, but simply because $s_{t}$ is free to vary while qit and pit are preset.

Empirical evidence suggests that both nominal and real exchange rates follow random walks, at least to a first approximation. 13 If $s_{t}$ and $r_{t}$ are assumed to follow random walks, then $x_{i t}$ can be written as follows: 14

$$
x_{i t}=\left(s_{t}-s_{t-1}\right)+\alpha_{1} r_{t-1}+\alpha_{0} E_{t-1} b_{t}
$$

The interpretation of this equation is quite interesting. Suppose that no pricing to market occurs $\left(\alpha_{0}=\alpha_{1}=0\right)$. Then $x_{\text {it }}$ is positively related to the current exchange rate surprise. But if no further surprises occur, the export-domestic price margin returns to its original level one period later since, in the absence of PTM, changes in st have no effect on the desired level of $x_{i t}$.

If pricing to market occurs, in contrast, the ratio of export to domestic prices in industry $i$ is related to the change 
in the spot exchange rate and to the level of the real exchange rate lagged one period as well as other lagged variables.

Nominal and real exchange rates are usually highly correlated, so it is normally difficult to separate their effects. But because it is the change in the nominal exchange rate rather than its level which enters the equation, it is possible to distinguish empirically between the effects of exchange rate surprises and pTr behavior. 15

The price series employed in the study represent goods aisaggregated into product groups such as color televisions and smal passenger cars rather than homogeneous comodities. Because price-setting patterns can differ across the goods in these groups, the observed novements in $x$ it may reflect prices set contemporaneously as well as prices preset on the basis of past expectations. Suppose that a fraction $\mathrm{kj}$ of the prices are set at period t-j so that the observed $x i t$ consists of a weighted average of prices set contemporaneously (with $t=0$ ) and those preset on the basis of t-j information (where $j$ can vary from 1 to $N$. Then $x_{i}$ is given by the following expression:

$$
\begin{gathered}
x_{i t}=\Sigma_{j=1} k_{j}\left(s_{t}-s_{t-j}\right)+\Sigma_{j=0} k_{j} \alpha_{i j} r_{t-j}+ \\
\Sigma_{j=0} k_{j} \alpha_{0 j} E_{t-j} b_{t}+u_{i t} .
\end{gathered}
$$

Ir this equation, a change in the nominal exchange rate between $t-j$ and $t$ leads to a rise in $x$ it by a fraction, $k j$, of the exchange rate change, where $k_{j}$ reflects the fraction of goods 
subject to a price-setting lag of $j$ periods. If the nominal exchange rate term includes several lags, the sum of the coefficients for this term gives the fraction of goods subject to price-setting lags of any length. 16

Both current and lagged real exchange rates enter the equation, with their respective coefficients reflecting the relative weight of contemporaneous and lagged pricing. Since goods with prices set with a $j$ period lag may have different PTM elasticities than those with some other lag, it is necessary to specify a different PTM elasticity, $\alpha_{1 j}$, for each lag length, $j$. $\alpha_{1}$ can then represent the weighted average PTM elasticity for the product group as a whole: $\alpha_{1}=\Sigma_{j=0} k_{j} \alpha_{1 j} \cdot 17$ similarly, in the case of the $b_{t}$ term, representing other independent variables in this equation, the sum of the coefficients of this term represents the weighted average elasticity of $x_{i}$ with respect to $b_{t}$. An error term, $u_{i t}$, represents random factors affecting industry pricing which are unobsezved by the econometrician.

\section{Estimation of the Price Equations}

This section reports equations explaining export-domestic price margins for seventeen Japanese products. The data are first described (with further detail provided in the data appendix), then the empirical results are discussed.

\section{A. Description of the Data}

The Bank of Japan reports prices for a large number of disaggregated products. 18 . This paper focuses on seventeen final products for which both export and domestic prices are available. 
The domestic prices are those reported at the primary wholesale level for sale in Japan, while the export prices are FoB export prices expressed in yen. The products are listed in Tables 1 and 2. Most of the products are drawn from the electrical machinery and transport industries. All of the products have significant export markets in the United states and other industrial countries, and most are products which have figured prominentiy in zecent trace discussions.

These products are exported to a wide range of countries. Thus the nominai and real exchange rates appearing in (19) should be effective exchange rates defined over prices and exchange rates for a number of countries which import Japanese products. The foreign output variable, similarly, should be a weighted average of foreign outputs. The United Nations reports export shares by product with categories roughiy corresponding to those in Tables 1 and 2.19 These export shares are used to form weights for product-specific series for the nominal and real exchange rates and foreign industrial production. For example, there are series for the nominal and real exchange rates and industrial production used in the equation for color televisions based on export shares for color teievisions.

To form the nominal exchange rate series for each product, the export shares for that product are used to weight the corresponding bilateral exchange rates forming a productspecifio, nominal efrective exchange rate. To form the real exchange rate series for each product, wholesale prices are first 
converted into dollars using monthly average exchange rates. When wholesale prices are not available, consumer prices are used instead. 20 The series for prices and bilateral exchange rates are reported in the International Monetary Fund, International Financial statistics. To obtain product-specific series for the real effective exchange rate, weighted averages of these national prices are formed using as weights the export shares for that product category. The real effective exchange rate is tren equal to the weighted average of foreign prices converted from dollars into yer and deflated by the Japanese wholesale price iraex. Twenty-two countries in all are represented in the exchange rate series. These counties account for between 64 pexcent and 93 percent of total Japanese exports depending on the product involved.

The industral production series are based on seasonally adjusted national series drawn from the OECD Main Economic Indicators. The aggregate series for each product are formed by weighting the national series by the export shares for that product. Thirteen countries in all are represented in the aggregate series.

The other independent variables in the estination are all Japanese variables: The real mage, wt - Pt, is derined as the nominal wage in Japanese manufacturing deflated by the Japarese wholesale price index. The relative price of raw materials, $p_{t}^{m}-$ Pt, is defined as the price of imported materials in yen deflated by the Japanese wholesale price index. Finaliy, 
Japanese output, $y_{t}$, is represented by industrial production since GNP data are not availabie monthiy. These independent variables did not prove to be statistically significant in most of the equations, although in several equations one or more were statisticaliy significant.

\section{B. Estimation Results}

Tables 1 and 2 report equations explaining the exportdomestic price margin for seventeen Japanese final products. The equations are estimated over the period from February 1980 to December 1987, so there are a total of 95 monthly observations.

To reduce spurious correlation between variables, each variable is expressed as the first-difference of its 109 value. The dependent variable in each equation is the export-domestic price margin for that product hexpressed as the Eirst-difference of its log value), defined as the price of exports in yen relative to the domestic price of that same product. The incependent variables consist of distributed lags for the firstdifferences of $\left(s_{t}-s_{t-j}\right), x_{t-j}$, and the other independent variables. St is the log value of the nominal effective exchange rate with weights basec on export shares for that product; $r_{t}$ is the log value of the real effective exchange rate with the same export shares.

The tables report the sum of the coefficients for each variable, with the t-statistic in parentheses below, and incicate the length of the lag if any. The tables also report the adjusted $R^{2}$, the Durbin-watson statistic, and the serial 
correlation coefficient (Rho) when it is statistically significant.

Table 1 presents the equations for eight products consisting of transport and tractor equipment. The first column of the table gives the sum of the coefficients for $\left(s_{t}-s_{t-i}\right)$, with the sum representing the share of that product subject to pricesetting lags of at least one period (as explained above). The second column gives the sum of the coefficients for $r_{t-j}$, the sum representing the weighted average provelasticity, $\alpha_{1}$. The thira columr gives the coefficients of any other independent variabies that are statistically significant. Hs expiained in section I. these variables enter the equation only if markup behavior is sufficiently different for the two markets.

In six of the elght equations, there are price-setting lags ranging from one to three months in length. With lags in pricesetting, some changes in export-domestic price margins are unintended and are therefore later reversed. In the case of small passenger cars, for example, the first coefficient of 0.332 indicates that a rise in the nominal exchange rate by one percent leads to a temporary increase in the export-domest price margin for small cars as a whole by over 0.3 percent for equivalently, that over 30 percent of that product category has the export-domestic price margin rise temporarily due to pricesetting lags). The second term in that equation gives the prM elasticity, the sustained effect on export-domestic price margins of a rise in the real exchange rate. For small passenger cars, 


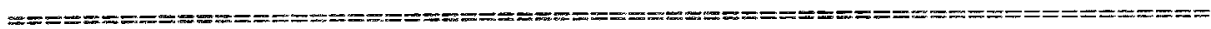

TABIE 1: $1980.02-1987.12$

EXPORT-DOMESTIC PRICE MARGIN IN JAPANESE MANUFACTURING TRBNSPORT AND TRACTOR EOUIPMENT

PRODUCT $\Sigma_{j} k_{j} \quad \Sigma_{j} k_{j} \alpha_{1} j \quad \Sigma_{j}=0 k_{j} \alpha_{01} j$ CONSTANT $\bar{R}^{2} / D W / R H O$

SPALI PASEENGER

\section{CARS 12 \\ CARS (2. .332}

month lag) $(3.79)^{a}$

VER

Prograns

.346

$(3.98)$

BASSENGER

$\begin{array}{lcc}\text { GARE } & .842 \\ (1 . \text { month }) & (12.3) & (9.72)\end{array}$

SNEL,

TRUCRS

TRUCKS

\begin{tabular}{|c|c|}
\hline$(2$ months) & $\begin{array}{c}.344 \\
(15.2)\end{array}$ \\
\hline
\end{tabular}

$$
.065
$$$$
\text { (1.68) }
$$$$
(2.51)
$$$$
-.001
$$

.001

(. 444$)$

.2010

(1. 63 )

.768

1.90

$$
\begin{aligned}
& .163^{b} \\
& (2.47)
\end{aligned}
$$

.001

.777

$(2.55)$

i. 94

.347
$(3.06)$

$$
\text { (2.54) }
$$$$
(-.526)
$$

.615

2.04 $-.355$

.076

1. 97

.001
$(.839)$

.726

I. 59

MOTOR

CYCLES

$\begin{array}{rr}.516 & -.179 d \\ (7.16) & (-1.81)\end{array}$

IIRES

TUBES

\begin{tabular}{|c|c|}
\hline$\frac{\text { TRACTORS }}{\text { (2 months }}$ & $\begin{array}{c}.376 \\
(2.14)\end{array}$ \\
\hline
\end{tabular}

EGRICUIIUPRI

\section{CONSTRUCTION}

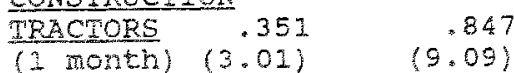

$$
-.001
$$$$
(-1,08)
$$

.279

2.08

$$
-.001
$$$$
(-.415)
$$

.690

2.02 .369

Notes: 2 The figures in parentheses below the coefficients are t-statistios.

$b$ The coefficient reported is for domestic output, $y_{t}$. The equation for small passenger cars also has a foreign output term, $-.359 \mathrm{z}$ with a t-statistic of $(-3.07)$. c PTM elasticity for voluntary export restraint period, April 1981 to the end of the sample period. dhe coefficient reported is for real wages, $w_{t}-p_{t}$. 
that PTM elasticity is .517 indicating that a rise in the real exchange rate by one percent raises the export price relative to the domestic price by over 0.5 percent.

The PTM elasticities are significantly greater than zero in all equations except the equation for small trucks. The coefficients range in size from 0.406 in the large truck equation to 1.14 in the tire and tube equation la coefficient which is insignificantly different srom one). So PTM behavior takes the standard form described in case 2 above: When there is a depreciation (appreciation) of the yer, Japanese firms raise (lower) their export prices relative to their domestic prices in order to limit changes in the foreigr currency prices of their products. 21 The exception is the equation for smali trucks where the PTM elasticity is small and insignificantly different from zero.

For several of the products, changes intrade restrictions may have altered PTM elasticities, so additional equations were estimated to investigate this possibility. The most prominent restriction may have been the voluntary export restraint on Japanese cars exported to the united states. This restraint was imposed beginning in April 1981, so in each of the passenger car equations a secona PTM elasticity was estimated defined over the period starting in that month. 22 This variable had no influence on export-donestic price margins in the (1arge) passenger car equation, but had a $t$-statistic of 1.63 in the equation for smal passenger cars (with engine displacement of 2000 co or lower). 
That equation is the second one reported in Table 1 . Similar attempts to model tariff restrictions on motorcycles and trucks proved to be unsuccessful. 23

In Table 1, other independent variables play some role in detemining export-domestic price margins. In the case of small passanger cars and small trucks, changes in Japanese industrial production increase this margin, while in the small passenger car equetion zoreign industrial production reduces the margin. 24 In the equation for motor cycles, a rise in the real wage decreases export-donestic price mergins.

table 2 reports equations for nine consumer products. The results parallel those of Table 1 although price-setting lags play jess of a role than in rable 2 . In five of the rine equations, there is evidence of a price-setting lag of at least one period indicating that excharge rate surprises lead to temporary changes in the export-domestic price margin. But in onjy two of these equations are the coefficients of the nominal exchange rate term statisticaly different from zero at the five percert level. And in most of the equations the sum of the coeficients reported is much less than one tranging from. 181 to .617\%, indicating that the fraction of each product subject to lags is relatively small.

The weighted average PTM elasticity, $\alpha_{1}$, in contrast, is significantly different from zero in all but one equation. So where is widespread evidence of pricing to market. Except in the equation for amplifiers, moreover, the pTM elasticity ranges 
TABLE 2: $1980.02-1987.12$

\section{EXPORT-DOMESTIC PRICE MARGIN IN JAPANESE MANUFACTURING} CONSUMER GOODS

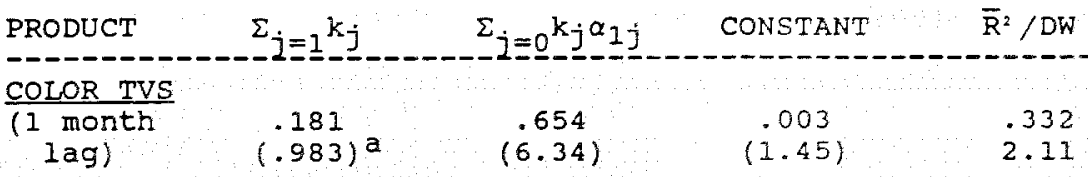

TAPE

$\left.\begin{array}{lccc}\hline \text { RECORDERS } & .338 & .950 & -.001\end{array}\right) .446$

TAPE

DECKS

$\begin{array}{lll}.588 & .000 & 237 \\ (5.50) & (.062) & 1.82\end{array}$

$\underline{R E C O R D}$

PLAYERS

$\begin{array}{rrr}.901 & -.003 & .330 \\ (6.87) & (-.819) & 2.11\end{array}$

AMPLIFIERS

(3. months)

$\begin{array}{cccc}.688 & 1.11 & -.001 & 597 \\ (3.25) & (6.61) & (-.495) & 1.78\end{array}$

MAGNETIC

RECORDING

.365

.872

.003

(1.07)

.292

TAPE: (1)

(1.37)

$(4.96)$

1.63

MICROWAVE

OVENS

$\begin{array}{lll}.278 & -.002 & .075 \\ (2.94) & (-.930) & 1.92\end{array}$

CAMERAS

$\begin{array}{lll}.079 & -.001 & .008 \\ (1.34) & (-.941) & 1.63\end{array}$

\section{COPYING}

MACHINES

Notes: a The figures in parentheses below the coefficients are t-statistics. 
between zero and one, and in the amplifier equation the coefficient is insignificantly different from one. ike in Tabie 1 , the prol elasticities in this table indicate strong evidence of pricing to market behavior of the conventional type: variations in the export-comestic price margin help to dampen the effects of exchange rate changes or export prices in coreign currency. The exception is the equation for cameras where the pro elasticity is small and insignificantly different srom zero. The evidence suggeste that in the case of cameras Japarese firms Lave not priced to narket, presumably because there are few producers of this product outside Japan. In none of the equations ir this table did the other independent variables prove so be statistically significant.

Most of the equations in Tables 1 and 2 explain a relatively high perentage of the variation in export-donestic price margine, particulariy considering the fact that the equations are estinated in first-difference form. The real exchange rate series provide nost of the explanatory power, as would be expected on the basis of the theoretical discussion in section $I$. c. Asymetries in Pricing to Market Behavior

The evidence strongly suggests that Japanese firms vary their export prices relative to their domestic prices in response to changes in real exchange rates. It may be the case, however, that Japanese fims follow different pricing behavior depending or whether the yen appreciates or depreciates. More specifically, in periods when the yen appreciates, these firms 
may vary the relative price of their exports more than when the yen depreciates. This asymetric pattern would hold if firms try to maintain market share by reducing export prices in yen when the yen appreciates but try to increase market share by holding export prices in yen constant when the yen depreciates. In this section, the paper investigates the hypothesis that PTM elasticities are larger in periods when the yen appreciates. $^{25}$ The period of study contains only one period of sustained appreciation, February 1985 to December 1987 . So the equations reported above were reestimated with an additional term representing the real exchange rate variable defined only over the period from February 2985 unt 1 the end of the sample period. The t-statistic for that additional term will indicate whether there is significantly greater price responsiveness in the period of the yen's appreciation.

Table 3 reports the equations where the additional PTH tem was statistically significant. The table includes the PTM elasticities neasured over the entire period as well as over the subperiod, together with the adjusted $R^{2}$ and DW statistics 26

There are five products which have statisticaliy significant PTM elasticities defined over the period of the yen's appreciation. In the case of three products small trucks, microwave ovens, and cameras, the prm elasticity defined over the whole period is statisticaly insignificant in the ecuation wher the elasticity for the recent period is estimated. So it appears that prior to 1985 Japanese firms did not vary the relative 
prices of these products. Two of these products, small trucks and cameras, were the only ones which fajled to show statistically significant PTM behavior in Tables 1 and 2 . In the case of the third product, microwave ovens, the pricing to market behavior reported in Table 2 is evidently just reflecting behavior since 1985 .

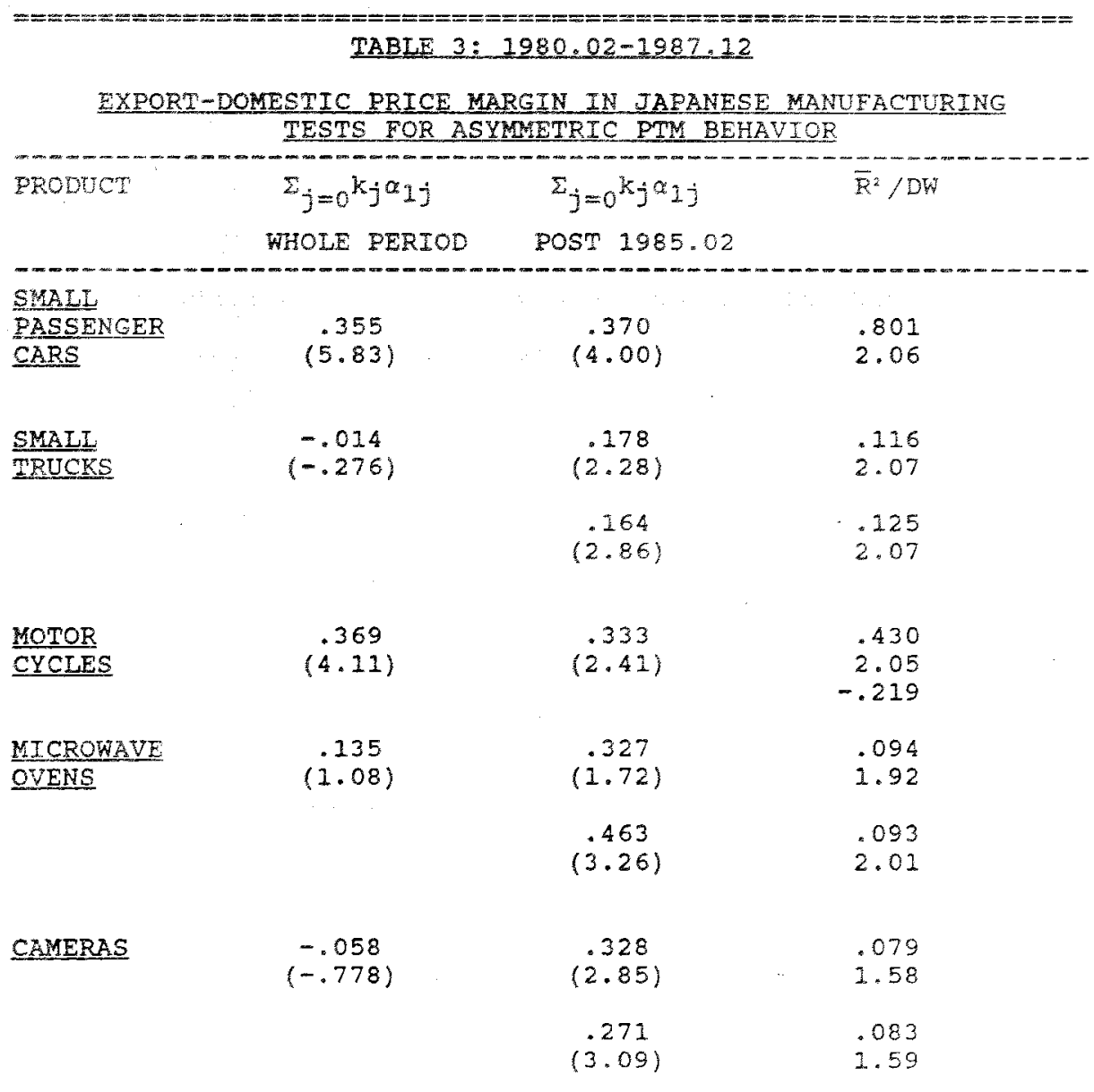


For the other two products in Table 3 , small passenger cars and motor cycles, both PTM elasticities are statistically significant. In these industries, Japanese firms evidentiy priced to market throughout the sample period, but varied their prices more sharply when the yen appreciated after 1985 . In the case of small passenger cars, for example, the PTM elasticity is only .355 defined over the entire sample period since 1980 , but the PTM elasticity defined over the pexiod since February 1985 is $.725(.355+.370)$.

In the case of the twelve other products in Tables 1 and 2 , there is no evidence of highe pTH elasticities in the period since February 1985 ; the coefficients of the PTM terms defined over the period since february 1985 are statistically insignificant at the five percent level. Thus pricing to market appears to be invariant with respect to the direction of exchange rate changes except for those five products reported in Table 3.

\section{Concluding Remarks}

This paper has investigated pricing to market by Japanese firms over the last eight years. The sample period inciudes a depreciation of the yen in real terms in the early 1980 s followed by a sharp appreciation. The paper studies how Japanese firms responded to shists in the real exchange rate by varying the prices of their exports relative to prices of products destined for the domestic maryet.

The paper provides strong evidace that export-donestic 
price margins are varied systematically in ways consistent with the theoretical model outlined above. The most important influence on these margins is the real exchange rate, with PTM elasticities being significantly greater than zero in all but two of the seventeen equations. There is some evidence that PTM elasticities are higher in periods when the yen appreciates, although this is true only in the case of five of the seventeen products. The estimation distinguishes between inadvertent but temporary changes in these margins due to exchange rate surprises and planned changes associated with PTM behavior. So the PTM elasticities which are estimated represent variations in this margin planned by Japanese firms to keep their products competitive abroad. The PTM elasticities vary widely across products, but there is overwhelming evidence that exportdomestic price margins are systematically varied to help Japanese firms protect their competitive position. Without PTM behavior, recent variations in real exchange rates would have placed a much greater burden of adjustment on Japanese output and employment. 


\section{REFERENCES}

Adler, Michael, and Bruce Lehmann, 1983, "Deviations from Purchasing Power Parity in the Long Run," Journal of Finance, December.

Baldwin, Richard, 1988, "Some Empirical Evidence on Hysteresis in Aggregate Import Prices," National Bureau of Economic Research Working Paper No. 2483 , January.

Cranda11, Robert W., 1987, "The Effects of U.S. Trade Protection for Autos and steel," Brookings Papers on Economic Activity. No. 1, $271-288$.

Feenstra, Robert C., 1987, "Symmetric Pass-Through of Tarifts and Exchange Rates under Imperfect Competition: An Empirical Test;" NBER working Paper No. 2453, December.

Froot, Kenneth $\mathrm{A}$, , and Paul Klemperer, 1988, "Exchange Rate PassThrough when Market Share Matters, " NBER Working Eaper No. 2542 ; March.

Giovannini, Alberto, 1988, "Exchange Rates and Traded Goods prices," Journal of International Economics, Eebruary, pp. $45-60$.

Krugman, Paul, 1987,.."Pricing to Market when the Exchange Rete Changes," in Sven $W$. Arndt and $J$. David Richardson, eds. ; RealFinancial inkages among open Economies, Cambidge: MrT Press, pp. $49-70$.

Mann, Catherine I., 1986, "Prices, Profit Margins, and Exchange Rates," Federal Reserve Bulletin, vol. 72 , No. 6 , June.

Meese, Richard $f .$, and Kenneth Rogoff, 1983, "Empirical Exchange Rate Models of the Seventies: Do They Fit out of Sample," Iournal of International Economics, February, pp. $3-24$.

1988, "Was it Real? The Exchange Rate-Interest Differential Relation over the Modern Floating-Rate-Peciod," Journal of Finance, September, $933-48$.

Ohno, Kenichi, 1988, "Export Pricing Behavior in Manufacturing: A U.S.-Japan Comparison, "I Jne.

Schembri, Lawrence, 1988, "Export Prices and Exchange Rates: An Industry Approach," Universities Research Conference on Trade Policies for International Competitiveness, Apil. 


\section{WRA ARPENDTX}

Japanese export prices and domestic prices: Export and domestic prices for the following goods: passenger cars, small passenger cars, trucks, small trucks, motor cycles, tires and tubes. agriculural tractors, construction tractors, oolor televisions, tape recorbers, tape decks, record players, ampilfiers, magnetic recording tape, microwave ovens, cameras, copying machines. The export prices are zOB prices expressed in yen, while the domestic prices are those reported at the primary wholesale level for sale in Japar. The inderes are calculated using the Laspeyres Eomula, Source: Bank of Japan, Price Indexes Annuel, various issues.

Iaprese wolesale orice Lndex: Source: IMF, Internationar Tinerial statistics.

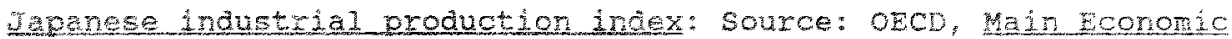
Hetotors.

Heduet-syecific nominal effective exchange rates: Formed as Heighted averages of nomina exchange rates (monthiy averages) expressed in yer/foreign currency. Source for exchange rates: IRe, except for wong kong where a series from WEA's Intitie Data Basc wased. The countries represented in the nominal and real efforive exchange rate series ware as follow the countries represter in the toreign industial production semies are

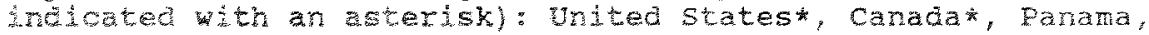
mong rong, Korea, Stropore, Beloium, Denmark, France*,

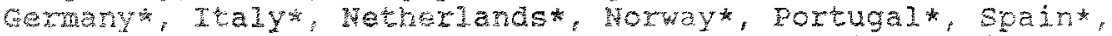
Swedert, Stitzerian, United Tingom, Malaysia, India, Saudi Habia, Fustraliak. The weights uged in foming these series are Japarese export shares fron United Nations, Commodity rrade statstices, 2986

Exodut-specific rea 1 effective exchange rates: Ratio of the foightod average foreign price expressed in yen to the Japanese wholesale price. The underiying price series are wholesale price indexes ror most countriss, consumer price indexes for france, Panare, Saudi Arabia, Malaysia, Portugaj. Source: IFS. For Hong Kong, an export price series was taken from WEF"s Intiline Data Base. The weights used in forming the foreign price series were the same as usec in forming the nominal effective exchange rates.

Poduct-specific foreion industrial production: weighted average of foreign industral production. The industrial production series are taken from the $\mathrm{HEI}$. The countries represented in the serbes are isted above with an asterisk.

Japanese wages: Monthly earnings in Japanese manufacturing, regular wokers, seasonally adjusted. Source: MEI.

Japanese raw materials price: Import price index for raw materials and ruel. Source: Price Indexes Annual. 


\section{FOOTNOTES:}

1. Other recent studies of pricing to market and the related phenomena of currency pass-through include Baldwin (1988), Feenstra (1987), Froot and Klemperer (1988), Giovannini (1988), Mann (1986), Ohno (1988), and Schembri (1988).

2. The firm's pricing policy might be undermined by third parties who buy in the low price market and sell in the high price market, but there are usually official and unofficial barriers to third party arbitrage for the types of products studied in this paper. Krugman (1987) cites the example of German automobiles whose prices in the United States greatly exceeded prices in Germany (expressed in dollars). A gray market developed for automobiles bought by third parties in Germany and shipped to the United states, but this gray market never eliminated the large margin between prices in the two markets.

3. $c_{1}$ is the derivative of the cost function with respect to its first argument, total output.

4. $M_{1}, N_{1}$ are the derivatives of the markup functions ith respect to their fixst arguments, relative prices. C 11 is the derivative of marginal cost $\left(C_{1}\right)$ with respect to total output. Similar notation is used for other derivatives.

5. For example, $H_{11}=\left[\left(P_{1} P_{4}\right) /\left(C_{1} h_{1}\right)\right] J_{1}$ where $[J]$ is the matrix of second derivatives of the profit furction. Since the second order conditions imply that [J] is negative semidefinite, $\mathrm{J}_{11}<0$. So $\mathrm{H}_{1 \mathrm{I}}>0$ since $\mathrm{C}_{1}>0$ li.e. marginal cost is positive) and $\hat{h}_{1}<0$ (the demand curve is negatively sloped).

6. The domestic markup elasticity can be written in terms of the elasticity of the demand curve as follows:

$$
\delta=-\left(\varepsilon_{\mathrm{p}} \mathrm{P}_{i t}\right) /\left(\epsilon(\epsilon-1) \mathrm{P}_{\mathrm{t}}\right)
$$

The derivative of the demand elasticity with respect to prices, $\epsilon_{p}$, depends on the curvature of the demand curve.

7. As Krugman (1987) points out, the dependence of PTM effects on demand behavior parallels the tariff effects in the recent theoretical i iterature on protection under imperfect competition. For a similar analysis of pass-through effects, see Feenstra (1987).

8. Feenstra (1987) describes this case as the "nomal" case. He shows that the passmthrough elasticity is between zero and minus one in this case. 
9. As discussed above, the markup elasticities depend on the derivatives of the demand elasticities with respect to prices, so it is curvature of the demand curves which matters, not just the elasticities themseives.

10. If both markup elasticities are negative (case 2 above), for examle, but the markup elasticity is greater in the foreign makhet $(T<\delta<0)$, then a rise in either cost factor reduces the ratio of corsign to domestic prices.

12. Since $c_{1}$ is homogeneous of degree one in factor prices, by Eule: 5 lay

$$
C_{12} W_{t}+C_{13} P=C_{1}
$$

The expresion $\alpha_{2}+a_{3}$, therefore, can be written as follows:

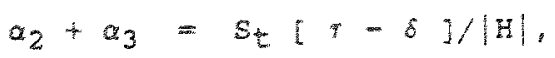

math

42. Giovannini (1988) andyzes a firms decision about whether to set prices in domestic or foreign currency. He is one of the ub other authors to distinquish between the effects of wanticipated changes in exchange rates and pricing to warket, athough his model of price-setting and approach to estimation ateser from this paper"s.

1. For evidence on the rando walk behatior of nomine and real

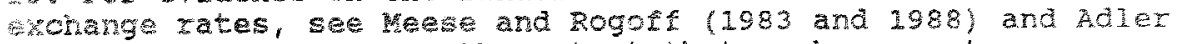
and behman (1983). To the extent that exchange $x$ thes wproxinate randor waks, changes in exchange rates can be sagarded se permanent. For a model in which temporary and proment changes in exhange rates have different effects, see troot and Klemperer (1988).

4. For example, st 15 assumed to follow a random wak process of sone form:

$$
s_{t}=s_{t-1}+v_{t}
$$

were $v_{t}$ is a random variable with an expected value of zero, so ${ }^{2}+15 t=s_{t-2}$

15. The correlation between changes in the nominal and real exchange rates between the yen and dollar is 0.969 over the sample period. But the correlation between the level of the real exchange rate and the change in the nominal exchange rate is sily 0.289.

16. Thus $\Sigma_{j=1} k_{j} \leq 1$ is the fraction of goods subject to pricesetting lags of any length, and $k_{0}=1-\Sigma_{j=1} k_{j}$ is the fraction 
of goods whose prices are set contemporaneously.

\section{The $k_{j}{ }^{\prime} s$ must sum to one when $j$ ranges from zero (contemporaneous pricing) to $\mathrm{N}$.}

18. Bank of Japan, Price Indexes Annual, various issues.

19. United Nations Commodity Trade Statistics 1986.

20. In the case of Hong Kong, export prices taken from WEF"'s INTLINE database are used in place of wholesale prices.

21. This strong evidence of pricing to warket is in contrast to the results of ohno (1988) tho found pricing to market ir on $y$ few products of Japanese manufacturing. onno is primarily interested in studying pass-tnrough behavior, so he estimates separate price equations for donestic and export prices and ther tests to see if the coefficients of the exchange rate ara different in the two equations. The tests reported here may be able to detect pricing to wazket more easily because the rato of the two prices is the aeperdent variable, so there is no need to simultaneously estimete the erects or cost and demand yaridales on each price.

22. For an analysis of the volumtary export restraint program, see Crambin $(1987)$.

23. Feenstra (1987) investigates the effects of these tarites in his study of pass-through. His study uses U. S. - Japan bilaterat unit value price data wich are probably better suited for examining the effects of U.S. tariffs than this study"s iultilateral series.

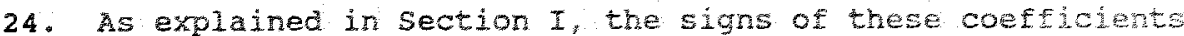
depend on the derivatives of the warkup functions which can be positive or negative.

25. Other studies which investigate different price beravioz in periods of appreciation and deprediation include Manr 11996 and ohno (1988).

26. Each equation is estimated in the same form as reportad in Tables 1 and 2 wth the exception of the adition of the pT tem defined over the period beginning in rebruary 1985 , although to conserve space the other terms in each equation are not reported in Table 3 . 